\title{
The Implementation of Novel Collaborative Structures for the Identification and Resolution of Barriers to Pluripotent Stem Cell Translation
}

David A. Brindley, 1,2,3,7,* Anna French,, 2,5,6 Jane Suh, 2,3,4 MacKenna Roberts, ${ }^{2}$ Benjamin Davies, ${ }^{1,2}$ Rafael Pinedo-Villanueva, ${ }^{1,11}$ Karolina Wartolowska, ${ }^{1,33}$ Kelly Rooke, ${ }^{1}$ Anneke Kramm, ${ }^{1}$ Andrew Judge, ${ }^{1,11}$ Mark Morrey, ${ }^{17}$ Amit Chandra, ${ }^{18}$ Hannah Hurley, ${ }^{2}$ Liam Grover, ${ }^{19}$ Ian Bingham, ${ }^{22}$ Bernard Siegel, ${ }^{23}$ Matt S. Rattley, ${ }^{30}$ R. Lee Buckler, ${ }^{10,16}$ David McKeon, ${ }^{24}$ Katie Krumholz, ${ }^{24}$ Lilian Hook, ${ }^{29}$ Michael May, ${ }^{25}$ Sarah Rikabi, ${ }^{5}$ Rosie Pigott, ${ }^{2}$ Megan Morys, ${ }^{2}$ Afsie Sabokbar, ${ }^{1}$ Emily Titus, ${ }^{25}$ Yacine Laabi, ${ }^{26}$ Gilles Lemaitre, ${ }^{26}$ Raymond Zahkia, ${ }^{26}$ Doug Sipp, ${ }^{27}$ Robert Horne, $, 2,7$ Christopher Bravery, ${ }^{31}$ David Williams, ${ }^{18}$ Ivan Wall, ${ }^{12,20,21}$ Evan Y. Snyder, ${ }^{13,14,15}$ Jeffrey M. Karp, ${ }^{3,8,9}$ Richard W. Barker, ${ }^{2, \dagger}$ Kim Bure, ${ }^{28, \dagger}$

Andrew J. Carr, ${ }^{1,2, \dagger}$ and Brock Reeve ${ }^{3, \dagger}$

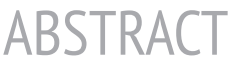

Increased global connectivity has catalyzed technological development in almost all industries, in part through the facilitation of novel collaborative structures. Notably, open innovation and crowd-sourcing-of expertise and/ or funding-has tremendous potential to increase the efficiency with which biomedical ecosystems interact to deliver safe, efficacious and affordable therapies to patients. Consequently, such practices offer tremendous potential in advancing development of cellular therapies.

In this vein, the CASMI Translational Stem Cell Consortium (CTSCC) was formed to unite global thought-leaders, producing academically rigorous and commercially practicable solutions to a range of challenges in pluripotent stem cell translation. Critically, the CTSCC research agenda is defined through continuous consultation with its international funding and research partners.

Herein, initial findings for all research focus areas are presented to inform global product development strategies, and to stimulate continued industry interaction around biomanufacturing, strategic partnerships, standards, regulation and intellectual property and clinical adoption.

\footnotetext{
${ }^{1}$ Nuffield Department of Orthopaedics, Rheumatology and Musculoskeletal Sciences, Nuffield Orthopaedic Centre, University of Oxford, Oxford, United Kingdom.

2 The Oxford-UCL Centre for the Advancement of Sustainable Medical Innovation (CASMI), The University of Oxford, Oxford, United Kingdom.

${ }^{3}$ Harvard Stem Cell Institute, Cambridge, Massachusetts.
}

\footnotetext{
${ }^{4}$ Harvard Department of Stem Cell and Regenerative Biology, Cambridge, Massachusetts.

${ }^{5}$ Nuffield Division of Clinical Laboratory Sciences, John Radcliffe Hospital, University of Oxford, United Kingdom.

${ }^{6}$ Stem Cell Research Laboratory, National Health Service Blood and Transplant, John Radcliffe Hospital, Oxford, United Kingdom.

${ }^{7}$ Centre for Behavioural Medicine, UCL School of Pharmacy, University College London, London, United Kingdom.
}

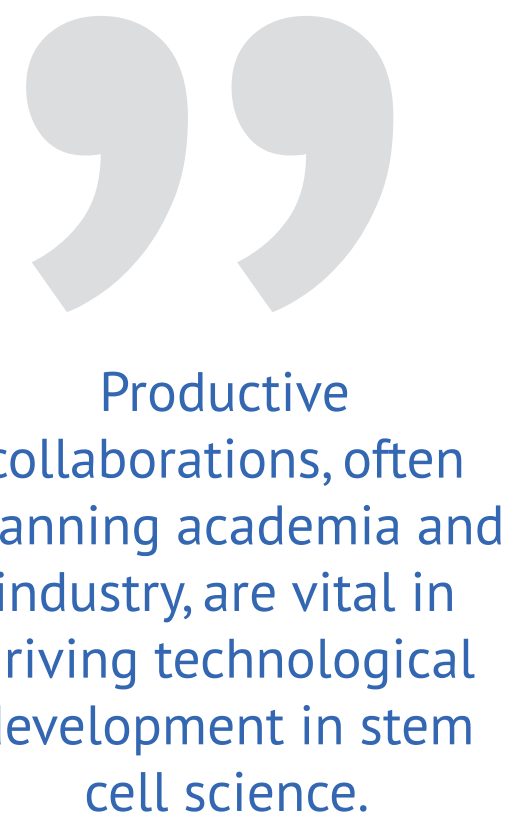

spanning academia and industry, are vital in driving technological development in stem cell science. 


\section{INTRODUCTION}

Stem cell technologies can stake a reasonable claim as the leading biomedical advancement of the new millennium. Previous decades were dominated by the elucidation of the structure of DNA, paving the way for progress in genomics and proteomics. Simultaneously, the socio-

${ }^{11}$ MRC Lifecourse Epidemiology Unit, Southampton General Hospital, Southampton, United Kingdom.

${ }^{12}$ Department of Biochemical Engineering, University College London, London, United Kingdom.

${ }^{13}$ Sanford-Burnham Medical Research Institute, La Jolla, California.

${ }^{14}$ Department of Pediatrics, University of California-San Diego, La Jolla, California.

${ }^{15}$ Sanford Consortium for Regenerative Medicine, La Jolla, California.

${ }^{16}$ Cell Therapy Group, Bellingham, Washington.

${ }^{17}$ Department of Orthopedic Surgery, Mayo Clinic, Minnesota.

${ }^{18}$ Centre for Biological Engineering, Wolfson School of Mechanical and Manufacturing Engineering, Loughborough University, Loughborough, United Kingdom.

${ }^{19}$ School of Chemical Engineering, University of Birmingham, Edgbaston, United Kingdom.

${ }^{20}$ Department of Nanobiomedical Science \& BK21 Plus NBM Global Reserch Center for Regenerative Medicine, Dankook University, Cheonan 330-714, Republic of Korea.

${ }^{21}$ Biomaterials and Tissue Engineering Lab, Department of Nanobiomedical Science and WCU Research Center, Dankook University, Cheonan, South Korea.

${ }^{22}$ IP Asset, Oxford, United Kingdom.

${ }^{23}$ Genetic Policy Institute, Palm Beach Executive Center, Palm Beach, Florida.

${ }^{24}$ The New York Stem Cell Foundation, New York, New York.

${ }^{25}$ The Centre for Commercialization of Regenerative Medicine, The Banting Institute, Toronto, Ontario, Canada.

${ }^{26}$ I Stem, Evry Cedex, France.

${ }^{27}$ RIKEN Center for Developmental Biology, Kobe, Japan.

${ }^{28}$ TAP Biosystems, Hertfordshire, United Kingdom.

${ }^{29}$ UK Cell Therapy Catapult Ltd, London, United Kingdom.

${ }^{30}$ Chemistry Research Laboratory, Department of Chemistry, University of Oxford, Oxford, United Kingdom.

${ }^{31}$ Consulting on Advanced Biologicals Ltd. Units 15 and16, London, United Kingdom.

*(Correspondence: david.brindley@ndorms.ox. ac.uk; david.brindley@casmi.org)

†Joint senior authors. economic context for scientific translation has evolved.

Reduced in-house research and development $(R \& D)$ productivity combined with increasing shareholder pressure in a challenging fiscal climate has catalyzed increased engagement between academia and industry. This has occurred via the provision of public-private partnerships, cross-licensing agreements, and other collaborative models. Concurrently, the roles of patient advocacy groups and disease-specific foundations have undergone extraordinary development, as observed in the recent approvals of Kalydeco (Ivacaftor; Vertex Pharmaceuticals, Cambridge, MA) and Glybera (Alipogene Tiparvovec; uniQure, Amsterdam, The Netherlands).

The demands of life science translation have changed; consequently, life science research is increasingly multidisciplinary and multi-institutional. However, the stem cell community has arguably been slow to respond to such changes in the ecosystems in which it operates, perhaps in part because of historic global and regional disharmonies in the funding landscape for stem cell technologies.

The Centre for the Advancement of Sustainable Medical Innovation (CASMI) Translational Stem Cell Consortium (CTSCC) was formed to redress this unacceptable status quo and act as a global nexus for stem cell translation.

Inspired by thought leaders in open innovation, the CTSCC aims to approach its research in two novel ways. First, it attempts to disaggregate the formulation of research problems from their delivery. In the past, research questions have been posed and answered by academia. Conversely, the research questions tackled by the CTSCC are formulated by a range of stakeholders in the stem cell translational pathway. This has been achieved by outlining their most pressing issues and assembling the very best teams to deliver academically rigorous and commercially practicable answers $[1,2]$. Second, the CTSCC attempts to utilize a require-

\section{FIG. 1. Overview of Key Stakeholders} in Biomedical Translation

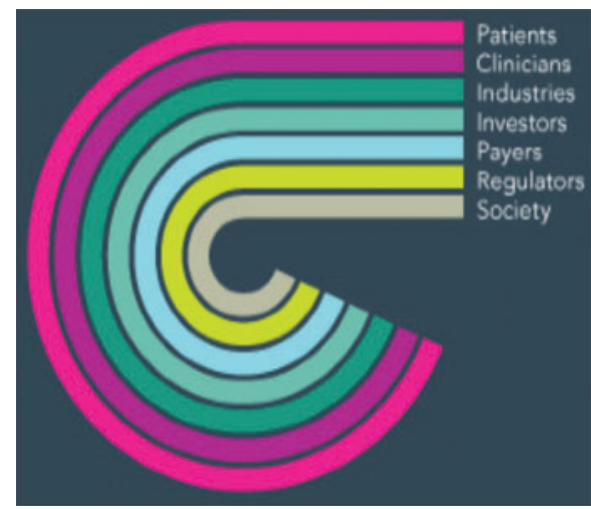

ments-based approach whereby the hurdles of potential technology adopters, including end users such as clinicians, are first assessed. Then, based upon these specifications, the highest possible impact contributions from all stakeholders are identified, including those from fundamental scientists (Fig. 1).

Accordingly, the principal translational needs identified by CTSCC partners are categorized into five focus areas: Standards, Biomanufacturing, Regulation and Intellectual Property, Strategic Partnerships, and Clinical Adoption. Additionally, the Consortium's technological focus is defined around pluripotent stem cells (PSCs), particularly induced pluripotent stem cells (iPSC) and embryonic stem cells, and their use in drug screening, as therapeutics themselves or as potential targets. However, because of the limited commercial development of PSC technologies to date [1-3], obtaining data from relevant nonpluripotent products is necessary to extrapolate likely future trends.

This unique and holistic approach to the effective and sustainable translation of stem cell technologies, generously supported by our funding and delivery partners, formally commenced in the elegant surroundings of the Saint James Club, Paris, France, on the July 30, 2013. Herein, we will provide an overview of the issues raised, which we hope will stimulate input from the global stem community. 


\section{Event structure}

The event format was based upon that of the Harvard Stem Cell Institute, Harvard Business School and Multiple Myeloma Foundation, 2nd Conference on Advancing the Role of Non-Profit Organizations in Drug Development, held on May 17, 2013 (Boston, MA).

The event was divided into five sections, reflecting the focus areas outlined above. Each section was framed by two short provocative presentations from academic and industry leaders, followed by roundtable discussions of precirculated questions (Table 1). Importantly, seating arrangements were made such that an expert from each focus area was seated at each table, to encourage interdisciplinary discussions. Primary discussion points were then summarized and debated by an

\section{Table 1. Roundtable and Panel Discussion Questions}

\begin{tabular}{|c|c|}
\hline Focus area & $\begin{array}{l}\text { Roundtable and panel } \\
\text { discussion questions }\end{array}$ \\
\hline Standards & $\begin{array}{l}\text { What are the key deficiencies in existing } \\
\text { iPSC and ESC standardization efforts, } \\
\text { and how can we best act to harmonize } \\
\text { these efforts? }\end{array}$ \\
\hline Biomanufacturing & $\begin{array}{l}\text { What are the key outstanding challenges } \\
\text { as we seek to remove the "art" and cost } \\
\text { from the manufacture of iPSC therapies? }\end{array}$ \\
\hline Strategic partnerships & $\begin{array}{l}\text { Which models for strategic partnerships } \\
\text { are accelerating stem cell translation } \\
\text { most effectively? And for those that are } \\
\text { not, why not? }\end{array}$ \\
\hline Regulatory and intellectual property & $\begin{array}{l}\text { Building on community experience with } \\
\text { ASCs, what regulatory uncertainties } \\
\text { remain with respect to ESCs and what } \\
\text { additional uncertainties are perceived } \\
\text { for iPSCs? }\end{array}$ \\
\hline Clinical adoption & $\begin{array}{l}\text { Failure to demonstrate sufficient efficacy } \\
\text { represents a major barrier to the } \\
\text { adoption of existing cellular therapeu- } \\
\text { tics. What steps (and data) are required } \\
\text { to confer stakeholder confidence and } \\
\text { successful adoption? }\end{array}$ \\
\hline
\end{tabular}

ASCs, adipose-derived stem cells; ESCs, embryonic stem cells; iPSCs, induced pluripotent stem cells. lated and have been incorporated into a questionnaire that has been distributed to all delegates who have been asked to prioritize, refine, and define the future work of the CTSCC.

\section{Overview of roundtable and panel discussions: Standards}

Defining standards for PSC technologies is inherently complex because of the heterogeneity and plasticity of both the cells themselves and their therapeutically relevant differentiated products $[4,5]$. Indeed, it is differences between these cells that will make one product a success and another product a failure in relation to expert panel. The points raised were col- a particular indication. Therefore, for PSC-derived cell products, the provision of a generalized standardization specification would be challenging. Similar challenges have been encountered in the clinical implementation of genomics in stratified medicines and their delivery through the use of companion diagnostics $[6,7]$.

Progress has been made with regard to the minimum requirements for PSC banking, as well as efforts to coordinate approaches and concepts in the academic R\&D space [12-14]. Characterization of cell therapies more broadly requires an assessment of cellular critical quality attributes associated with identity, purity, potency, and safety (Table 2). Approaches taken to assess PSC identity include transcriptomics, analysis of the phosphoproteome, expression of pluripotency markers, telomere length, and epigenetic signatures [15-19].

Rapid technological progress within the field, such as the generation of iPSC lines using small molecules alone, will likely continue with vigor [8] further stimulating efforts to standardize iPSC lines suitable for clinical and industrial use [9]. Reference standards for methodologies and instrumentation would bring a wide range of benefits, facilitating comparability and reproducibility, which are fundamental challenges for the sector. Reference standards are also a decisive requirement for the development of manufacturing instrumentation and reagents, as well as for the manufacturing process itself [10]. Furthermore, reference standards would enable productive communication with the regulatory authorities and provide a positive step toward global harmonization [11]. Pertinent questions relate to the type of in-process measurements that should be recorded and their acceptable ranges, including the identification of permissible and potentially efficacious ranges for PSC products.

Pluripotency potential, in relation to the ability to differentiate into all three germ layers, has been commonly assessed by embryoid body differentiation, teratoma formation, and directed differentiation 
Table 2. FDA Definitions of Critical Quality Attributes as Per CFR 21600.3 and Part 610

\begin{tabular}{|l|l|}
\hline Safety & $\begin{array}{l}\text { “...the relative freedom from harmful } \\
\text { effect to persons affected, directly or } \\
\text { indirectly, by a product when prudently } \\
\text { administered taking into consideration } \\
\text { the character of a product in relation to } \\
\text { the condition of the recipient at the } \\
\text { time." } \\
\text { "...relative freedom from extraneous } \\
\text { matter in the finished product, whether } \\
\text { or not harmful to the recipient or } \\
\text { deleterious to the product. Purity } \\
\text { includes but is not limited to relative } \\
\text { freedom from residual moisture or other } \\
\text { volatile substances and pyrogenic } \\
\text { substances." } \\
\text { “...is interpreted to mean the specific } \\
\text { ability or capacity of the product, as indi- } \\
\text { cated by appropriate laboratory tests or } \\
\text { by adequately controlled clinical data } \\
\text { obtained through the administration of } \\
\text { the product in the manner intended, to } \\
\text { effect a given result." }\end{array}$ \\
\hline
\end{tabular}

methodologies. Therapeutic potency assays for differentiated cell types, however, will vary on a cell type-to-cell type and indication basis. With PSC products, it may become increasingly necessary to model the in vivo environment in vitro, to predict cell identity and potency in a physiologically relevant context. Moreover, for the scalable and reproducible generation of PSC products, nondestructive methods to continuously monitor and characterize cells in real time are required. Biomaterials may play a pivotal role in controlling the environment of implanted cells, in addition to biodistribution and engraftment profiles [20,21]. Here, the triad of cell therapy, host, and biomaterial interaction must be predicted. In summary, standardization efforts in the PSC sector should focus on defining methods, and instrumentation to accelerate effective translation.

\section{Biomanufacturing}

Firmly positioned at the interface of the focus areas selected for investigation, responsive, and others informative. For example, technical specifications for biomanufacturing equipment respond to the needs defined by clinicians, operators, validation teams, and regulators. However, bioprocessing parameters can also inform the work of fundamental scientists and development groups, particularly around standardization of industrial-scale processes. These are then subject to current Good Manufacturing Practice (cGMP) requirements, which seek to remove the "art" from inherently manual (and hence variable) laboratory processes [22] (Table 3).

Encouragingly, there is evidence that the expertise required to conform to cGMP standards, often limited in academia, is being provided by public and/or privately funded translation centers. Additionally, contract manufacturing organizations are engaging at progressively earlier stages of development with academia and/or smallable benefits in expanding communication biomanufacturing is in some respects medium enterprise. There are consider- between academia and early-stage providers so that initial processes are amenable to industrial scale-up.

Throughout the day, a number of lessons were highlighted that can be learnt from the evolution of cell-based high-throughput screening technologies and early monoclonal antibody manufacturing strategies. Critically, the provision of in-process analytical technologies and process automation advances [23] will facilitate improvements in the consistency of cellular bioprocesses and the comparability of products manufactured - an essential step toward broad stakeholder adoption [24].

Additionally, strong market prospects exist to innovate better cGMP-level processing tools that are cognizant of the final product sterilization limitations to develop microcarriers or aggregate processes for bioreactor production and to adapt existing process and media development technologies for cost of goods reductions $[25,26]$. Media development and in-process technologies to monitor expansion and differentiation of stem cell-derived products in real time represent a major unmet market need [27]. Also, novel release criteria offer opportunities for bioprocess engineers to develop noninvasive monitoring and testing platforms to enable thorough product characterization, a necessity for biologically active products [28].

\section{Strategic partnerships}

Successful translation of scientific discoveries from the lab to the clinic requires the coordination of multiple stakeholders in the healthcare industry who are each crucial to the translational process. This interdisciplinary network, its utility and its effectiveness, plays an important role in stem cell science. Therefore, the emergence of strategic partnerships in the stem cell space has demonstrated that productive collaborations, often spanning academia and industry, are vital in driving technological developments [29]. As such, it is critical to understand the various partnerships that have been forged to date and 
Table 3. Evaluation of Biomanufacturing Automation

\begin{tabular}{|c|c|}
\hline $\begin{array}{c}\text { Advantages of } \\
\text { biomanufacturing automation }\end{array}$ & $\begin{array}{l}\text { Disadvantages of } \\
\text { biomanufacturing automation }\end{array}$ \\
\hline Improved reproducibility & Initial capital expenditure \\
\hline Reduced contamination risks & Potentially limited flexibility \\
\hline Potential for improved product quality & Physical footprint \\
\hline Enhanced productivity & Staff training requirements \\
\hline $\begin{array}{l}\text { Electronic process monitoring and } \\
\text { record retention }\end{array}$ & Operational costs, including servicing \\
\hline Reduced labor costs & Reliability concerns \\
\hline
\end{tabular}

identify which models for strategic partnerships are accelerating stem cell translation most effectively. It is hoped that these findings may also elucidate new opportunities for collaborations that could address translational gaps.

First, when academia, foundations, service providers, and/or pharmaceutical companies enter into collaborations, it is imperative that all partners have clearly aligned interests and a shared vision. Increasingly, it is essential that university technology transfer offices are engaged in this process, to ensure that underlying intellectual property (IP) licensing agreements support, as opposed to constrain, multistakeholder collaborations.

In order for the partnership to add value, groups should communicate how each partner can combine their capabilities, expertise, and resources in the most effective and additive manner. Examples of some categories of strategic partnerships that have been formed within the stem cell landscape are: academic and industry partnerships for commercializing early-stage stem cell research; academic and industry partnerships for advancing the clinical translation of stem cell therapeutics; public and private partnerships for launching specific stem cell initiatives; strategic partnerships for improved manufacturing of stem cell products; and strategic partnerships involving major publicly funded translational institutions. However, academic-industry partnerships-including with CMOs and/ or CROs - have been less common than hoped. Consequently, it is essential to thorels to ensure that the objectives of all parties are effectively aligned.

While the growing number of strategic partnerships is an excellent catalyst for stem cell translation, it is crucial that patient benefit is not delayed because of the poor coordination of partner contributions. This is a critical role of the growing international network of stem cell translation centers. However, several significant questions remain, including, center, what are their optimal funding sources and capabilities, and how should access to said resources be allocated among stakeholders? By comparing commonalities between different centers and understanding their strengths and weaknesses, we aim to suggest the criteria of effective models for future strategic partnerships - within and beyond the stem cell community.

\section{Regulation and IP}

Stem cell therapy has stimulated the emergence of a new area of interest in law, particularly concerning the optimal routes by which to capture value in the development and delivery of cell-based technologies. An example would be the oughly evaluate existing partnership modhow exactly we define a translation as yet unproven value of (biomanufacturing) process patents. Consequently, some investor hesitance persists.

The stem cell IP landscape is vast and poorly understood, despite a number of efforts to perform broad IP landscaping exercises (Table 4). However, prior studies failed to effectively distinguish between different aspects of stem cell R\&D. Patent data analytic software offers a powerful tool to mine and reveal decisive trends and information, since a number of factors can skew results, such as delays in the granting of applications in the face of different regulatory challenges.

Therefore, the value and best practices for freedom-to-operate licensing schemes, such as that offered by iPS Academia Japan, remains uncertain. Other proposed solutions include creating a stem cell research exemption to patent infringement and compulsory broad licensing for publicly funded discoveries. There may be a requirement for novel mechanisms that facilitate collaboration and expedite commercial translation through patent brokering or clearing houses, without undermining industrial proprietary value. However, it is reasonable to assert that the impact of such challenges will decline overtime as the number of clinical stage, and ultimately revenue-generating products, increases.

Regulation is a challenging topic in that few PSC technologies are near a clinical stage; therefore, regulatory recommendations must be based on similar technologies and assessed potential risks. Significant risks debated at the event were biodistribution, tracking, cell overgrowth, immunogenicity, inappropriate homing, teratoma formation, and allowable residual pluripotent cell level in final differentiated product. The impact of deficiencies in regulatory training for academics was also highlighted.

Historically, regulatory standards have commonly relied heavily on defining the basis of the mechanism of action for the treatment, which in many cases is not fully elucidated for cellular therapeutics. 


\section{Table 4. Notable Stem Cell Intellectual Property Landscape Reports}

\begin{tabular}{|c|c|c|}
\hline Title & Publication date & Source \\
\hline Regenerative Medicine Report & July 2013 & $\begin{array}{l}\text { (UK) House of Lords Science and Technology Commit- } \\
\text { tee: www.publications.parliament.uk/pa/ld201314/ } \\
\text { ldselect/ldsctech/23/23.pdf }\end{array}$ \\
\hline $\begin{array}{l}\text { Induced Pluripotent Stem Cells: A US Patent } \\
\text { Landscape Analysis }\end{array}$ & May 2013 & $\begin{array}{l}\text { Konski A F, S Elliott, Genetic Engineering and } \\
\text { Biotechnol Rev, 33(13); raw data published by } \\
\text { Californian Institute for Regenerative Medicine } \\
\text { (CIRM): www.cirm.ca.gov/our-funding/stem-cell- } \\
\text { research-resources }\end{array}$ \\
\hline $\begin{array}{l}\text { Statement on Data and Materials Sharing and } \\
\text { Intellectual Property in Pluripotent Stem Cell } \\
\text { Science in Japan and China }\end{array}$ & November 2012 & $\begin{array}{l}\text { The Hinxton Group: www.hinxtongroup.org/consen } \\
\text { sus_hg12_final.pdf }\end{array}$ \\
\hline $\begin{array}{l}\text { Stem Cells: The UKNSCN Patent Watch } \\
\text { Landscape }\end{array}$ & June 2012 & $\begin{array}{l}\text { (UK) Intellectual Property Office, Patent Informatics } \\
\text { Team and the UK National Stem Cell Network: www.ipo } \\
\text {.gov.uk/informatic-stemcells.pdf }\end{array}$ \\
\hline $\begin{array}{l}\text { Taking Stock of Regenerative Medicine in the } \\
\text { United Kingdom }\end{array}$ & July 2011 & $\begin{array}{l}\text { (UK) Dept. of Health, Dept. for Business Innovation and } \\
\text { Skills, Office of Life Sciences: www.gov.uk/govern } \\
\text { ment/uploads/system/uploads/attachment_data/ } \\
\text { file/32459/11-1056-taking-stock-of-regenerative- } \\
\text { medicine.pdf }\end{array}$ \\
\hline $\begin{array}{l}\text { Regenerative Medicine: The Patent Landscape } \\
\text { in } 2011\end{array}$ & June 2011 & $\begin{array}{l}\text { (UK) Intellectual Property Office, Patent Informatics } \\
\text { Team: www.ipo.gov.uk/informatic-regenmed.pdf }\end{array}$ \\
\hline $\begin{array}{l}\text { Intraoperability Problems: Inconsistent Stem } \\
\text { Cell IP and Research Regimes Within Nations }\end{array}$ & May 2011 & $\begin{array}{l}\text { Murdoch CJ, Stanford Journal of Law, Science and } \\
\text { Policy, vol. } 3\end{array}$ \\
\hline $\begin{array}{l}\text { Statement on Policies and Practices Governing } \\
\text { Data and Materials Sharing and Intellectual } \\
\text { Property in Stem Cell Science }\end{array}$ & January 2011 & $\begin{array}{l}\text { The Hinxton Group: www.hinxtongroup.org/consensus_ } \\
\text { HG10_FINAL.pdf }\end{array}$ \\
\hline $\begin{array}{l}\text { Human Induced Pluripotent Stem Cells: A Review } \\
\text { of the US Patent Landscape }\end{array}$ & July 2010 & $\begin{array}{l}\text { Georgieva B P, J M Love; Regen Med, Vol 5(4): 581-591 } \\
\text { (doi:10.2217/rme.10.43) }\end{array}$ \\
\hline The Intellectual Property Landscape for iPS Cells & December 2009 & $\begin{array}{l}\text { Feldman R, D Furth, Stanford Journal of Law Science and } \\
\text { Policy, vol. } 3 \text { (doi: 2010) }\end{array}$ \\
\hline $\begin{array}{l}\text { Stem cell patents: a landscape analysis } \\
\text { An evaluation of the development of innovation } \\
\text { in stem cell technologies by network analysis of } \\
\text { stem cell patent filings }\end{array}$ & August 2009 & Konski A F, D J F Spielthenner, Nat Biotechnol, 27(8) \\
\hline $\begin{array}{l}\text { The Global Stem Cell Patent Landscape: } \\
\text { Implications for Efficient Technology Transfer } \\
\text { and Commercial Development }\end{array}$ & April 2007 & Bergman K, GD Graff, Nat Biotechnol, 25:419-424 \\
\hline $\begin{array}{l}\text { Intellectual Property of Human Pluripotent } \\
\text { Stem Cells }\end{array}$ & August 2006 & $\begin{array}{l}\text { Rohrbaugh M L, Ch 5, Regenerative Medicine, (US) } \\
\text { Department of Health and Human Bergman: } \\
\text { stemcells.nih.gov/info/scireport/pages/2006 } \\
\text { Chapter5.aspx }\end{array}$ \\
\hline Stem Cells: IP Landscape & January 2006 & $\begin{array}{l}\text { Esmond R W, R A Schwartzman, T J Ebersole, Intellec- } \\
\text { tual Property and Tech Law J of Weil Gotshal and } \\
\text { Manges LLP, 18(1) }\end{array}$ \\
\hline
\end{tabular}


Appropriately, there remains a strong regulatory stimulus for the development of in vivo monitoring technologies to determine cell engraftment, distribution, and fate.

To produce affordable therapies, duplicate costs and delays to meet unnecessary regulatory standards must be avoided. Presently, separate regulatory approvals are required for multiple components of combinational products (cells + biomaterials). Although there are strong regulatory arguments for this approach, there is also compelling evidence from a practical and commercial perspective against this approach — not least because of the unique financial risks associated with the development of combinational products [21]. Subsequently, bolstered stakeholder efforts are required to investigate robust risk:benefit appraisal methodologies for cell-based therapies (Table 5).

\section{Clinical adoption}

Stem cells of all varieties have held the promise of delivering a wide variety of healthcare treatments for a number of years; however, in most cases their broad clinical efficacy is yet to be satisfactorily established. The academic and professional literature is replete with short case series and reports detailing their use in small numbers of patients, while only a limited number of comparative trials have been conducted [30]. From a clinical perspective, the most significant question to consider with any new product is: Does this provide a better outcome for the patient than currently available treatments? The second consideration is: At what cost does this improvement come? Establishing answers to these questions are essential steps in the broad adoption of cell-based thera-
Table 5. Challenges in the Risk:Benefit Appraisal of Cell-Based Healthcare Innovations

1. Limited, but rapidly growing; development and implementation of risk:benefit appraisal methodologies for all types of healthcare innovation to date

2. Transient vs. permanent characteristics of cell-based therapies and impact on duration of exposure to risks and/or benefits

3. Limited clinical data for pluripotent cell types

4. Lack of defined mechanisms of action (MoAs)-in part due to limitations in cell characterization and standardization

5. Limited regulatory guidance specifically for the risk:benefit appraisal of cell-based therapies. However, a growing body of regulatory guidance exists for established technologies.

\section{Conflation of product (allogeneic) and service (autologous) models}

7. Difficulties in defining the scope of risk:benefit analysis for cell-based therapies. For example, may extend to the risks conferred by final formulation and fill procedures in hospital pharmacies

8. Requirement to assign appropriate "utility weightings" to alternate risk:benefit factors under analysis

9. Need for academia-initiated clinical studies to include (qualitative and quantitative) risk:benefit evaluations, which may be unfamiliar to academic investigators

10. Unique challenges of assessing the combined risk and benefits of combinational products (cells + biomaterial)

11. Requirement for patient stratification and effective integration into risk:benefit analyses

12. Challenges in defining appropriate patient follow-up durations and frequencies pies and/or biomaterials, requiring appropriately designed and conducted clinical trials.

Clinical trials must be designed to enable the comparison of new technologies with the currently accepted gold standard [31]. For instance, in the treatment of cartilage defects in the knee, comparisons to microfracture, the best available option currently in use, are most appropriate and will provide the most relevant clinical data. The relatively high cost of cell-based treatments is solely justified, if they provide long-term

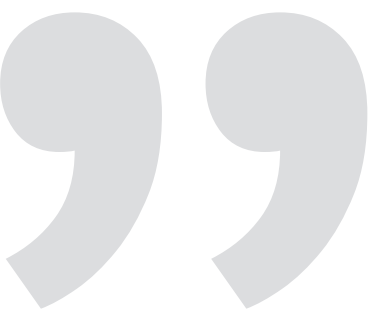

From a clinical perspective, the most significant question to consider with any new product is: Does this provide a better outcome for the patient than

\section{currently available treatments?}

symptom relief. Autologous chondrocyte implantation and similar stem cell-based treatments are only legitimately cost effective from a healthcare system point of view if they lead to a significant delay in the necessity for end-stage treatments such as joint arthroplasty when compared with procedures such as microfracture [32].

Equally critical is the selection of appropriate endpoints and follow-up timeframes. Validated clinical outcome measures are vital to allow for a reproducible assessment of interventions and to monitor long-term progress. Of equal importance is the assurance that follow-up periods are sufficiently long enough to determine whether 


\section{Table 6. Barriers to Clinical Adoption of Cell-Based Therapies}

\begin{tabular}{|c|c|}
\hline Issue & Potential solution \\
\hline High cost of procedure & $\begin{array}{l}\text { Demonstrate superior long-term } \\
\text { outcomes compared with current } \\
\text { potentially more affordable treatment } \\
\text { options }\end{array}$ \\
\hline Increased morbidity & $\begin{array}{l}\text { Demonstrate short-term morbidity } \\
\text { offset by long-term outcomes }\end{array}$ \\
\hline Difficulty in treatment comparison & $\begin{array}{l}\text { Ensure that robust outcome measures } \\
\text { are used in all trials to allow comparison } \\
\text { between them }\end{array}$ \\
\hline Requirement for long-term benefit & $\begin{array}{l}\text { Adequately designed clinical trials with } \\
\text { appropriate follow-up periods }\end{array}$ \\
\hline Lack of clinical engagement & $\begin{array}{l}\text { Ensure that clinicians involved in } \\
\text { initial design stages of interventions } \\
\text { and trials }\end{array}$ \\
\hline
\end{tabular}

treatment is worthwhile in the long-term and to monitor treatment reproducibility in the target patient population. It is also imperative that trials be conducted so that all results are reported in a manner that allows representative comparison and does not neglect negative outcomes. This can then inform the optimal patient selection for the specific cell-based treatment and correctly assess the full impact upon the healthcare infrastructure (Table 6).

Finally, clinician engagement can be assured only upon demonstration that the new technologies are effective in both mediumand long-term to warrant the increased cost and potential heightened short-term morbidity for patients. Achieving these aims can be greatly assisted by establishing early clinician involvement in both initial product development and trial design.

\section{CONCLUSION}

The multistakeholder pursuit of sustainable and efficient stem cell translation is essential to the delivery of patient outcomes. However, as this event demonstrates, this remit will not be achieved unless rigorous and continuous assessments of the translational environment are conducted-not least the requirements of ultimate clinical adopters.
Therefore, while existing efforts of translatory and trade organizations in the stem cell space to convene multistakeholder meetings are welcomed, arguably their value has been limited by the quality of the interaction between the participants. As such, the most impactful discussions and collaborative relationships forged at this meeting are a result of disaggregating the formulation and delivery of research questions - a process supported by a (mildly) draconian seating arrangement forcing unconventional multidisciplinary interactions.

Hence, the stem cell community needs to innovate and translate more effectively, with a focus on clinical and commercial needs, and we firmly believe that the work of the CTSCC will continue to be an essential mechanism to facilitate this.

We extend our sincere thanks to all participants in the CTSCC's activities, including this meeting, and look forward to contributing academically rigorous and commercially practicable findings to the global stem cell technology industry.

\section{ACKNOWLEDGMENTS}

We wish to extend our thanks to the following individuals whose contributions have been critical to the development of the CTSCC: Stewart Abbot (Celgene), Houman Ashrafian (University of Oxford), Elona Baum (Californian Institute for Regenerative Medicine [CIRM]), Robert Beale (Cystic Fibrosis Foundation), Chas Bountra (University of Oxford), James Bradner (Harvard), John Brown (UK Cell Therapy Catapult), Guillermo-Garcia Cardena (Harvard), Dan Cho (Centre for Applied Research [CFAR]), Emanuela Costigliola (GE), George Church (Harvard), George Daley (Harvard), Barry Dornfeld (CFAR), Nick Edwards (CASMI), Simon Ellison (UK Cell Therapy Catapult), Paul Fairchild (University of Oxford), Thomas Fellner (Lonza), Kathy Giusti (Multiple Myeloma Research Foundation), Joe Gold (Stanford University), Christopher Huge (CFAR), Johan Hyllner (UK Cell Therapy Catapult), Perry Karsen (Celgene), Karim Lakhani (Harvard Business School [HBS]), Mark Lewis (Loughborough University), Neil Littmann (CIRM), Andrew Lo (MIT), Lorenz Mayr (AstraZeneca), Alison McEwen (UK Trade and Investment/(UK) Foreign and Commonwealth Office), Stephen Minger (GE), David Newble (TAP Biosystems), Mahendra Rao (NIH Center for Regenerative Medicine), William Sahlman (HBS), John Sinden (ReNeuron), Sue Solomon (New York Stem Cell Foundation), Matthias Steger (Roche), Molly Stevens (Imperial College London), Thomson Reuters IP Team (London), Keith Thompson (UK Cell Therapy Catapult), Sam Ulin (ClearView Healthcare Partners), Nat Welch (CFAR), Michael West (BioTime), Joe Wu (Stanford University), and Jesus Zurdo (Lonza).

We wish to express our sincere thanks to the following organizations that have contributed to the consortium as funding and events partners - without whom the consortium and the benefits it will bring to stem cell translation would be unacceptably constrained: GE Healthcare, CCRM, TAP Biosystems, Lonza, CIRM, SENS Research Foundation, UK Cell Therapy Catapult, and NIH Centre for Regenerative Medicine. Additionally, CASMI is a past recipient of funding from the Technology Strategy Board in order to support an investigation into cell therapy regulation. 
Author disclosure

\section{statement}

The content outlined herein represents the individual opinions of the authors and may not necessarily represent the viewpoints of their employers. D.A.B. gratefully acknowledges support from the SENS Research Foundation (Mountain View, CA). D.A.B. is a stockholder in Translation Ventures Ltd. (Charlbury, Oxfordshire, UK), a company that amongst other services provides cell therapy biomanufacturing, regulatory, and financial advice to clients in the cell therapy sector. D.A.B. is subject to the CFA Institute's Codes, Standards, and Guidelines, and as such, this author must stress that this piece is provided for academic interest only and must not be construed in any way as an investment recommendation. Additionally, at time of publication, D.A.B. and the organizations with which he is affiliated, may or may not have agreed and/or pending funding commitments from the organisations named herein. All other authors, do not declare any additional conflicts of interest, as defined by the journal. However, are happy to respond to direct requests for confirmation; and stress that affiliations stated may or may not constitute a disclosure of employment and/or ownership of financial instruments in the named entity.

\section{REFERENCES}

1. Guinan E, KJ Boudreau and KR Lakhani. (2013). Experiments in open innovation at Harvard Medical School. MIT Sloan Manage Rev 54:45-53.

2. Lakhani KR, KJ Boudreau, PR Loh, L Backstrom, C Baldwin, E Lonstein, M Lydon, A Maccormack, RA Arnaout and EC Guinan. (2013). Prize-based contests can provide solutions to computational biology problems. Nat Biotechnol 31:108-111.

3. French A, RL Buckler and DA Brindley. (2013). Commercialization of regenerative medicine: learning from spin-outs. Rejuvenation Res 16:164-170.
4. Bilican B, A Serio, SJ Barmada, AL Nishimura, GJ Sullivan, M Carrasco, HP Phatnani, CA Puddifoot, D Story et al. (2013). Comment on "Drug Screening for ALS Using Patient-Specific Induced Pluripotent Stem Cells. Sci Transl Med 5:188-189. 5. Cahan P and GQ Daley. (2013). Origins and implications of pluripotent stem cell variability and heterogeneity. Nat Rev Mol Cell Biol 14:357-368.

6. Barker RW, DA Brindley and A Schuh. (2013). Establish good genomic practice to guide medicine forward. Nat Med 19:530.

7. De Jong JP, DE Grobbee, B Flamion, SR Forda and HG Leufkens. (2013). Appropriate evidence for adaptive marketing authorization. Nat Rev Drug Discov 12:647-648. 8. Hou P, Y Li, X Zhang, C Liu, J Guan, H Li, T Zhao, J Ye, W Yang et al. (2013). Pluripotent stem cells induced from mouse somatic cells by small-molecule compounds. Science 341:651-654.

9. Pistollato F, S Bremer-Hoffmann, L Healy, L Young and G Stacey. (2012). Standardization of pluripotent stem cell cultures for toxicity testing. Expert Opin Drug Metab Toxicol 8:239-257.

10. Brindley DA, IB Wall and KE Bure. (2013). Automation of cell therapy biomanufacturing: minimizing regulatory risks and maximizing return on investment. Bioprocess Int March, 42-49.

11. Bianco P, R Barker, O Brustle, E Cattaneo, H Clevers, GQ Daley, M De Luca, L Goldstein, O Lindvall et al. (2013). Regulation of stem cell therapies under attack in Europe: for whom the bell tolls. EMBO J 32:1489-1495.

12. Adewumi O, B Aflatoonian, L Ahrlund-richter, M Amit, PW Andrews, G Beighton, PA Bello, N Benvenisty, LS Berry et al. (2007). Characterization of human embryonic stem cell lines by the International Stem Cell Initiative. Nat Biotechnol 25:803-816.

13. International Stem Cell Banking Initiative. (2009). Consensus guidance for banking and supply of human embryonic stem cell lines for research purposes. Stem Cell Rev 5:301-314.

14. Marti M, L Mulero, C Pardo, C Morera, M Carrio, L Laricchia-Robbio, CR Esteban and JC Izpisua belmonte. (2013). Characterization of pluripotent stem cells. Nat Protoc 8:223-253.
15. Bock C, E Kiskinis, G Verstappen, H Gu, G Boulting, ZD Smith, M Ziller, GF Croft, MW Amoroso et al. (2011). Reference Maps of human ES and iPS cell variation enable high-throughput characterization of pluripotent cell lines. Cell 144:439-452.

16. Muller FJ, BM Schuldt, R Williams, D Mason, G Altun, EP Papapetrou, S Danner, JE Goldmann, A Herbst et al. (2011). A bioinformatic assay for pluripotency in human cells. Nat Methods 8:315-317.

17. Marion RM, K Strati, H Li, A Tejera, S Schoeftner, S Ortega, M Serrano and MA Blasco. (2009). Telomeres acquire embryonic stem cell characteristics in induced pluripotent stem cells. Cell Stem Cell 4:141-154.

18. Tobe BT, J Hou, AM Crain, I Singec, EY Snyder and LM Brill. (2012). Phosphoproteomic analysis: an emerging role in deciphering cellular signaling in human embryonic stem cells and their differentiated derivatives. Stem Cell Rev 8:16-31.

19. Meissner A. (2010). Epigenetic modifications in pluripotent and differentiated cells. Nat Biotechnol 28:1079-1088.

20. Place ES, ND Evans and MM Stevens. (2009). Complexity in biomaterials for tissue engineering. Nat Mater 8:457-470.

21. Pashuck ET and MM Stevens. (2012). Designing regenerative biomaterial therapies for the clinic. Sci Transl Med 4, 160 sr4.

22. Davie NL, DA Brindley, EJ CulmeSeymour, C Mason. (2012). Streamlining Cell Therapy Manufacture From Clinical to Commercial Scale. BioProcess International 10:24-49.

23. Thomas RJ, A Chandra, PC Hourd and DJ Williams. (2008). Cell culture automation and quality engineering: a necessary partnership to develop optimized manufacturing processes for cell-based therapies. J Lab Automat 13:152-158.

24. Archer R and DJ Williams. (2005). Why tissue engineering needs process engineering. Nat Biotechnol 23:1353-1355.

25. Brandenberger R, S Burger, A Campbell, F Fong, E Lapinska and JA Rowley. (2011). Cell therapy bioprocessing. Bioprocess Int 9:30-37.

26. McCall MJ and DJ Williams. (2013).

Developing cell therapies: enabling cost 
prediction by value systems modeling to manage developmental risk. J Commercial Biotechnol 19:27-39.

27. Baptista RP, DA Fluri and PW Zandstra. (2013). High density continuous production of murine pluripotent cells in an acoustic perfused bioreactor at different oxygen concentrations. Biotechnol Bioeng 110:648-655.

28. Brindley D, K Moorthy, JH Lee, C Mason, HW Kim and HW Wall I. (2011).

Bioprocess forces and their impact on cell behavior: implications for bone regeneration therapy. J Tissue Eng 2011, 620247. 29. Rao M. (2013). Public private partnerships: a marriage of necessity. Cell Stem Cell 12:149-151.

30. Gerlier L, M Lamotte, M Wille, PC Kreuz, J Vanlauwe, D Dubois and FM Meurgey. (2010). The cost utility of autologous chondrocytes implantation using ChondroCelect(R) in symptomatic knee cartilage lesions in Belgium. Pharmacoeconomics 28:1129-1146.
31. Pastides P, M ChimutengwendeGordon, N Maffulli and W Khan. (2013). Stem cell therapy for human cartilage defects: a systematic review. Osteoarthritis Cartilage 21:646-654.

32. Steinert AF, L Rackwitz, F Gilbert, U Noth and RS Tuan. (2012). Concise review: the clinical application of mesenchymal stem cells for musculoskeletal regeneration: current status and perspectives. Stem Cells Transl Med 1:237-247. 